\title{
Isolated small bowel angio-oedema due to ACE inhibitor therapy
}

\author{
Naveen Voore, Vincent Stravino
}

Department of Internal Medicine, Riverside Shore Memorial Hospital, Nassawadox, Virginia, USA

Correspondence to Dr Naveen Voore, voorenaveen@yahoo.com

Accepted 8 October 2015

CrossMark

To cite: Voore $\mathrm{N}$

Stravino V. BMJ Case Rep Published online: [please include Day Month Year] doi:10.1136/bcr-2015212623

\section{DESCRIPTION}

A 43-year-old woman presented with abdominal pain, nausea and vomiting for 1 week. She had a history of hypertension and hyperlipidaemia. Her home medications included omeprazole and simvastatin, and, starting 4 weeks prior, lisinopril. On presentation, vital signs were stable. The patient did not have rash, urticaria or facial swelling, but was found to have a diffusely tender abdomen with hypoactive bowel sounds.

Laboratory evaluation revealed normal white cell count, comprehensive metabolic panel, amylase and lipase. CT scan of the abdomen showed circumferential wall thickening of the small bowel, inflammation, oedema of surrounding mesentery and mild ascites (figures 1 and 2). The patient was admitted, and treated with intravenous hydration and empiric antibiotics for presumed colitis. Her home medications were held due to persistent vomiting. Further, stool studies including clostridium difficile, Shiga toxin and campylobacter antigen, as well stool cultures, were normal. Later serologies including C1 esterase and complement levels were also normal.

The patient's symptoms improved by the fifth day of hospitalisation. She was started on clear liquids followed by soft diet a day later. Blood pressure medication was resumed once she tolerated the soft diet, and her abdominal symptoms

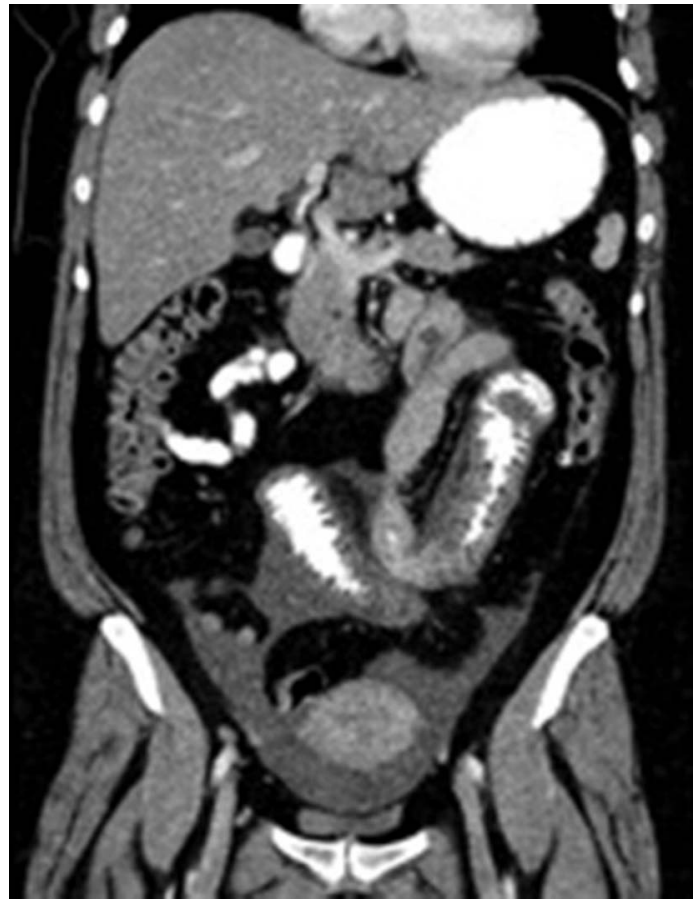

Figure 1 CT scan of the abdomen showing bowel wall thickening and free fluid in the pelvis. returned within a day. Based on her recurrent symptomology and temporal association, we considered 'visceral angioedema due to use of ACE inhibitor (ACEi)'. We completely discontinued lisinopril and started the patient on amlodipine for blood pressure control, which she tolerated well without any adverse events. After discharge, the gastroenterologist followed her up a month later. She remained asymptomatic, and underwent a colonoscopy, which found her to be normal, with no evidence of inflammation.

Angio-oedema is a complication of ACEi therapy, with an incidence of up to $0.5 \% .^{1}$ Isolated small bowel angio-oedema is even rarer and often unrecognised. Usually, symptoms start within $48 \mathrm{~h}$ after initiation of ACEi, but they can be delayed for months to years. Apart from ACEi, other medications, such as omeprazole, may also cause small bowel angio-oedema. ${ }^{2}$ In this case, omeprazole was excluded as a cause since there were no reported symptoms after initiation of this medication. The exact pathogenesis of this unique and rare condition is poorly understood. The possible explanations include bradykinin accumulation, C1 esterase deficiency or antigen-antibody interaction. ${ }^{3}$

The most common symptoms associated with small bowel angioedema are nausea, vomiting and abdominal pain. In most instances, the symptoms occur soon after initiation of the medication and resolve once the offending medication is withdrawn. The diagnosis of this condition is largely based on clinical symptoms and radiological findings. Visceral angioedema has a very limited differential diagnosis including C1 esterase inhibitor deficiency and infectious, inflammatory and ischaemic colitis, which were excluded in our patient

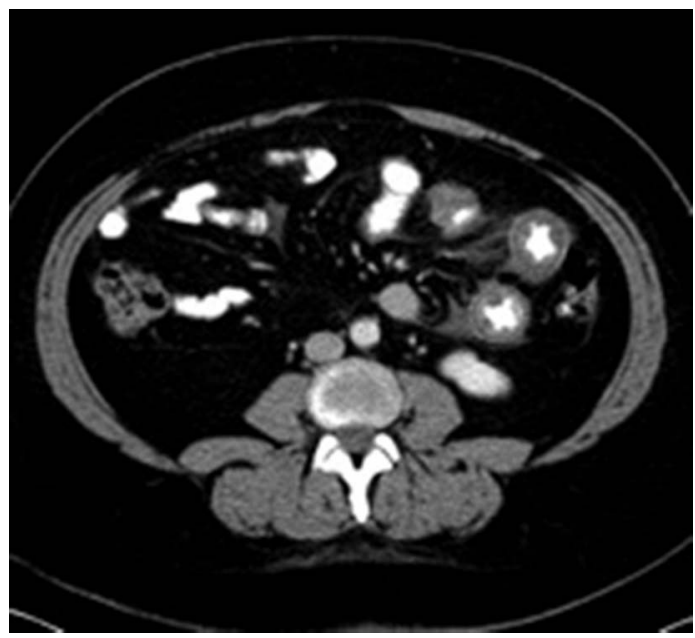

Figure 2 CT scan of the abdomen showing circumferential thickening of the small bowel. 
after laboratory evaluation of C1 esterase and complement levels, the clinical course of the patient and subsequent colonoscopy after discharge. Treatment involves supportive care including bowel rest, pain control, intravenous hydration and discontinuation of the ACEi.

Isolated small bowel angio-oedema due to use of an ACEi is rare, and often underreported and unrecognised.

Early diagnosis is needed to prevent unwarranted investigations and surgical interventions.

Contributors NV was involved in the patient's care and treatment, and also in writing and editing of the manuscript. VS helped with manuscript writing and editing.
Competing interests None declared.

Patient consent Obtained.

Provenance and peer review Not commissioned; externally peer reviewed.

\section{REFERENCES}

1 Bloom AS, Schranz C. Angiotensin-converting enzyme inhibitor-induced angioedema of the small bowel—a surgical abdomen mimic. J Emerg Med 2015;48:e127-9.

2 Bowlby HA, Dickens GR. Angioedema and urticarial associated with omeprazole confirmed by drug rechallenge. Pharmcotherapy 1994;14:119-22.

3 Campbell T, Peckler B, Hackstadt RD, et al. ACE inhibitor-induced angioedema of the bowel. Case Rep Med 2010;2010:690695.

Copyright 2015 BMJ Publishing Group. All rights reserved. For permission to reuse any of this content visit http://group.bmj.com/group/rights-licensing/permissions.

BMJ Case Report Fellows may re-use this article for personal use and teaching without any further permission.

Become a Fellow of BMJ Case Reports today and you can:

- Submit as many cases as you like

- Enjoy fast sympathetic peer review and rapid publication of accepted articles

- Access all the published articles

- Re-use any of the published material for personal use and teaching without further permission

For information on Institutional Fellowships contact consortiasales@bmjgroup.com

Visit casereports.bmj.com for more articles like this and to become a Fellow 